\title{
Biodiversity of soil bacteria exposed to sub-lethal concentrations of phosphonium- based ionic liquids: Effects of toxicity and biodegradation
}

Sydow, Mateusz; Owsianiak, Mikoaj; Framski, Grzegorz; Woniak-Karczewska, Marta; Piotrowska-Cyplik, Agnieszka; awniczak, ukasz; Szulc, Alicja; Zgoa-Grzekowiak, Agnieszka; Heipieper, Hermann J; Chrzanowski, ukasz

\section{Published in:}

Ecotoxicology and Environmental Safety

Link to article, DOI:

10.1016/j.ecoenv.2017.08.026

Publication date:

2018

Document Version

Peer reviewed version

Link back to DTU Orbit

Citation $(A P A)$ :

Sydow, M., Owsianiak, M., Framski, G., Woniak-Karczewska, M., Piotrowska-Cyplik, A., awniczak, ., Szulc, A., Zgoa-Grzekowiak, A., Heipieper, H. J., \& Chrzanowski, . (2018). Biodiversity of soil bacteria exposed to sublethal concentrations of phosphonium-based ionic liquids: Effects of toxicity and biodegradation. Ecotoxicology and Environmental Safety, 147, 157-164. https://doi.org/10.1016/j.ecoenv.2017.08.026

\section{General rights}

Copyright and moral rights for the publications made accessible in the public portal are retained by the authors and/or other copyright owners and it is a condition of accessing publications that users recognise and abide by the legal requirements associated with these rights.

- Users may download and print one copy of any publication from the public portal for the purpose of private study or research.

- You may not further distribute the material or use it for any profit-making activity or commercial gain

- You may freely distribute the URL identifying the publication in the public portal 
1 Sydow, M., Owsianiak, M., Framski, G., Woźniak-Karczewska, M., Piotrowska-Cyplik, A., 2 Ławniczak, Ł., Szulc, A., Zgoła-Grześkowiak, A., Heipieper, H.J., Chrzanowski, Ł., 2018. 3 Biodiversity of soil bacteria exposed to sub-lethal concentrations of phosphonium-based ionic 4 liquids: Effects of toxicity and biodegradation. Ecotoxicol. Environ. Saf. 147, 157-164. 5 doi:10.1016/j.ecoenv.2017.08.026 
6 Biodiversity of soil bacteria exposed to sub-lethal concentrations of phosphonium-based

8

9 Mateusz Sydow ${ }^{1}$, Mikołaj Owsianiak ${ }^{2}$, Grzegorz Framski ${ }^{3}$, Marta Woźniak-Karczewska ${ }^{1}$, 10 ionic liquids: effects of toxicity and biodegradation Agnieszka Piotrowska-Cyplik ${ }^{4}$, Łukasz Ławniczak $^{1}$, Alicja Szulc ${ }^{1}$, Agnieszka ZgołaGrześkowiak $^{1}$, Hermann J. Heipieper ${ }^{5}$, Łukasz Chrzanowski ${ }^{1, *}$

${ }^{1}$ Faculty of Chemical Technology, Poznan University of Technology, Berdychowo 4, 60-965 Poznań, Poland

${ }^{2}$ Division for Quantitative Sustainability Assessment, Department of Management Engineering, Technical University of Denmark, Produktionstorvet, Building 424, DK-2800 Kgs. Lyngby, Denmark

${ }^{3}$ Institute of Bioorganic Chemistry, Polish Academy of Sciences, Noskowskiego 12/14, 61704 Poznań, Poland

${ }^{4}$ Institute of Food Technology of Plant Origin, Poznan University of Life Sciences, Wojska Polskiego 31, 60-624 Poznań, Poland

${ }^{5}$ Department of Environmental Biotechnology, Helmholtz Centre for Environmental Research - UFZ Permoserstrasse 15, 04318 Leipzig, Germany

*Corresponding author - tel.: +48 6166537 16; fax: +48 616653649 .

E-mail address: lucaschrz@gmx.de (Ł. Chrzanowski) 


\section{Abstract}

28 Little is known on the effect of ionic liquids (ILs) on the structure of soil microbial communities and resulting biodiversity. Therefore, we studied the influence of six trihexyl(tetradecyl)phosphonium ILs (with either bromide or various organic anions) at sublethal concentrations on the structure of microbial community present in an urban park soil in 100-day microcosm experiments. The biodiversity decreased in all samples (Shannon's index decreased from 1.75 down to 0.74 and OTU's number decreased from 1399 down to 965) with the largest decrease observed in the microcosms spiked with ILs where biodegradation extent was higher than $80 \%$. (i.e. $\left[\mathrm{P}_{66614}\right][\mathrm{Br}]$ and $\left[\mathrm{P}_{66614}\right][2,4,4]$ ). Despite this general decrease in biodiversity, which can be explained by ecotoxic effect of the ILs, the microbial community in the microcosms was enriched with Gram-negative hydrocarbondegrading genera e.g. Sphingomonas. It is hypothesized that, in addition to toxicity, the observed decrease in biodiversity and change in the microbial community structure may be explained by the primary biodegradation of the ILs or their metabolites by the mentioned genera, which outcompeted other microorganisms unable to degrade ILs or their metabolites. Thus, the introduction of phosphonium-based ILs into soils at sub-lethal concentrations may result not only in a decrease in biodiversity due to toxic effects, but also in enrichment with ILs-degrading bacteria.

Keywords: biodegradation; ionic liquids; microbial community; biodiversity; toxicity; 


\section{Introduction}

Ionic liquids (ILs) are a group of chemical compounds composed of an organic cation and an organic or inorganic anion, which have melting point below $100^{\circ} \mathrm{C}$. The salts based on imidazolium or ammonium cations are among the two most popular and well-studied groups of ILs (Coleman and Gathergood, 2010; Cvjetko Bubalo et al. 2014). In the recent years, however, the phosphonium-based ILs became popular due to relatively low costs of their synthesis and relatively good thermal stability. Tetraalkylphosphonium ionic liquids are used as solvents, catalysts, electrolytes and corrosion inhibitors (Fraser and MacFarlane 2009). This group of ILs has been used in industrial processes, such as the isomerisation of 3,4epoxybut-1-ene to 2,5-dihydrofuran carried out by the Eastman Chemical Company (IL used as catalyst) or the production of pharmaceutical intermediates by utilizing Sonogashira coupling conducted by the Central Glass Co., Ltd., Japan (IL used as solvent) (Plechkova and Seddon, 2007). In general, ILs can be ecotoxic when they enter aquatic or terrestrial ecosystems (Pham et al. 2010). Several papers focused on the evaluation of the environmental impacts of ILs (Ferlin et al. 2013a, 2013b, Liwarska-Bizukojc and Gendaszewska 2013, Peric et al. 2013, Pernak et al. 2011, Ventura et al. 2013, Borkowski et al. 2016). However, the number of scientific reports studying the impact of ILs on the structure of indigenous microbial communities inhabiting soil is still insufficient (Lawniczak et al. 2016), as the majority of the studies is focused on the effects of ILs on single microbial species (Piotrowska et al. 2017).

The influence of ILs on complex microbial communities inhabiting soil can be evaluated using Illumina Next-Generation Sequencing Technology (Illumina NGS), which produces useful high-throughput $16 \mathrm{~S}$ amplicon data. Thereby, Illumina NGS enables an insight into the diversity of microbial taxa at the great scale and coverage (Caporaso et al. 2012; You et al. 2016). While most studies focused on the assessment of ecotoxicity reports regarding their fate and exposure, including biodegradability and persistence, are limited. Biodegradation tests are mainly conducted with the use of imidazolium-, ammonium-, and pyridinium-based ionic liquids, whereas the number of studies dedicated to phosphoniumbased ILs is still limited. Moreover, most of the biodegradation assays are predominantly based on the use of short-term OECD tests (with a 28-day test time window) and there is little information regarding the long-term ( $>28$ days) biodegradability of phosphonium-based ILs. Furthermore, the data from biodegradation studies carried out in the terrestrial environment with respect to based ILs are scarce, as the number of reports dedicated to this topic is limited 
(Modelli et al. 2008; Pham et al. 2010). The results obtained in our previous study showed that primary biodegradation of selected phosphonium-based ILs in urban park microcosms was low and reached 25 and $29 \%$ for $\left[\mathrm{P}_{66614}\right][\mathrm{Cl}]$ and $\left[\mathrm{P}_{66614}\right][\mathrm{Tr}]$, respectively (Sydow et al. 2015).

The aim of this study was to determine the effect of six selected trihexyl(tetradecyl)phosphonium ILs with either inorganic or different organic anions supplied at sub-lethal concentrations on the structure of soil bacterial and resulting changes in biodiversity. The experiments were carried out in soil microcosms and lasted for 100 days. The soil has document biodegradation potential toward other phosphonium-based ionic liquids (Sydow et al. 2015). Yet, apart from [ $\left.\mathrm{P}_{66614}\right][\mathrm{Br}]$, the studied ILs are antifungal agents and are expected to influence biodiversity mainly through ecotoxic effects of the attached anions (Walkiewicz et al. 2010). The determination of structural changes within the community was assessed using Illumina NGS genetic assay, supported by determination of ILs' biodegradation in the soil combined with determination of 100-day $\mathrm{CO}_{2}$ evolution from the soils spiked with the ILs. The soil used in the experiments was an urban park soil with some potential for biodegradation of ionic liquids (Sydow et al. 2015).

\section{Materials and methods}

\subsection{Chemical reagents}

The phosphonium-based ILs were prepared according to method described by CienieckaRosłonkiewicz et al. (2005). Briefly, trihexyl(tetradecyl)phosphonium bromide was prepared in the reaction of trihexylphosphine and 1-bromotetradecane. The azolate ILs were synthesized according to the method described by Walkiewicz et al. (2010). The water content of synthesized ILs was determined by Aquastar volumetric Karl-Fischer titration with Composite 5 solution as the titrant and anhydrous methanol as solvent. The water content of each of the ILs reached values lower than $500 \mathrm{ppm}$. The compounds were also characterized by ${ }^{1} \mathrm{H}$ and ${ }^{13} \mathrm{C}$ NMR spectroscopy and elemental analysis as described in Walkiewicz et al. (2010). The list of the studied ILs as well as their chemical structures is presented in Table 1.

\subsection{Characterization of soil}

Mollic gley soil was collected from a city park in the center of Poznan city (N 52.4011445, E 16.9222993) in September 2013 from the depth of 10-20 cm according to the procedure described by Alef and Nannipleri, (1995). According to United Soil Classification System, the 
soil used in the experiments is characterized as fine grained silt loam type OL belonging to organic silts and organic silty clays of low plasticity. The soil was stored in closed 5-L polypropylene containers for one week at constant temperature equal to $20^{\circ} \mathrm{C}$. Prior to the experiments, the soil was sieved and analyzed according to the procedures described by Adeboye et al. (2011). The composition and full characteristics of the soil can be found in Sydow et al. (2015).

\subsection{Determination of sub-lethal concentrations}

In order to assess the potential toxicity of the used ILs and estimate sub-lethal concentration of each ILs which could be used in biodegradation tests (ion residues, $\mathrm{CO}_{2}$ evolution) and genetic assay (Illumina NGS), the preliminary test - seed germination assay - with the use of grass species was conducted. The preliminary test was chosen to be carried out using plants, as the most convenient method of toxicity assessment in soil. The $\mathrm{EC}_{50}$ values (the concentration of a chemical at which $50 \%$ of its effect is observed) of ILs were determined by assessing seeds germination with increasing (total) concentrations $(125 ; 250 ; 500 ; 1000$; 2000; 4000; $8000 \mathrm{mg} \mathrm{kg}^{-1}$ ) of a particular IL in soil. A mix of seeds (Festuca rubra 40\%; Festuca arundinacea 20\%; Agrostis capillaris 4\%; Poa pratensis 6\%; Festuca trachyphylla $30 \%$ ) was used in the test. After 14 days of growth, above-ground parts of germinated seeds were collected and weighed. Triplicate sets were performed for each treatment. The $\mathrm{EC}_{50}$ values were determined using the Trimmed Spearman-Karber method (An 2004). The SPEARMAN program (EPA's Center for Exposure Assessment Modeling, USA), was used to calculate the $\mathrm{EC}_{50}$ values.

\subsection{Preparation of soil samples}

The experiments in soil were carried out in sealed 1-L glass bottles (one bottle corresponds to one sample), which contained $100 \mathrm{~g}$ of urban park soil and were not inoculated. The samples were prepared as follows: $10 \mathrm{~g}$ of non-sterilized soil were added into bottles and then spiked with a methanol solution $(5 \mathrm{~mL})$ of each IL to reach a final concentration equal to previously determined $\mathrm{EC}_{50}$ (i.e. 3010 - $3960 \mathrm{mg} \mathrm{kg}^{-1}$, which corresponds to 0.0237 - 0.0401 [M]). Next, methanol was evaporated with nitrogen. Afterwards, untreated soil in the amount of 90 grams was added. The soil was later vigorously mixed. Finally, the microcosms were incubated at $20^{\circ} \mathrm{C}$ for 100 days. The set-up for the tests consisted of 18 samples contaminated with ILs (i.e. 3 replicate samples for each IL), 3 additional samples for monitoring of the soil moisture 
and 3 control samples (spiked only with methanol, which was then evaporated with nitrogen). The base traps containing $\mathrm{NaOH}$ solution were placed inside each bottle (mostly to be used for $\mathrm{CO}_{2}$ evolution tests) to maintain full saturation in the microcosms, as it provided equilibrium between the headspace phase and the soil. Therefore the moisture content of the soil was constant during the experiments and was equal to $18 \pm 2 \%$. Each of the bottle replicates was used for three different tests i.e. one bottle with soil was used for genetic assay (20g of the soil was used for Illumina NGS assay) biodegradation test ( $0.5 \mathrm{~g}$ of the soil was used for HPLC-MS analysis) and $\mathrm{CO}_{2}$ evolution tests (base traps were placed inside the bottles).

\subsection{Assessment of bacterial community structure in soil using Illumina sequencing}

Illumina Next-Generation Sequencing (NGS) enables to study qualitative and quantitative composition of microbial samples at all taxonomic ranks - from kingdom to species level. Here, Illumina genetic assay was employed in order to assess the effects of the used ILs on the structure of the microbial community inhabiting urban park soil. Although it can be expected that some filamentous fungi are resistant to ionic liquids (Petkovic et al. 2009), this study was limited only to Bacteria and Archaea kingdom. It is mostly caused by the fact that the studied phosphonium-based ILs were designed as antifungal agents (mostly due to antifungal properties of the attached anions) and are toxic toward fungi (Walkiewicz et al. 2010). In this study, the contribution of the particular microbial taxon was presented as \% of total taxa (regarding the same taxonomic rank). Class, family and genus taxonomic ranks were chosen to be presented in results section, as changes on these levels enable the comparison of the microbial community structure between samples. The detailed NGS data containing the information about the contribution of taxa in all taxonomic ranks can be found in the NCBI Nucleotide Archive database under the project number PRJNA389990 (https://www.ncbi.nlm.nih.gov/sra/SRP109755). BioSample accessions: SAMN07257075

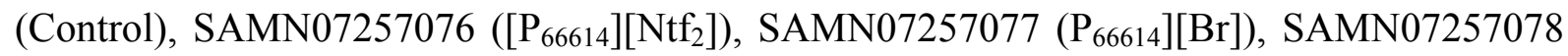
$\left(\left[\mathrm{P}_{66614}\right][3 \mathrm{AT}]\right), \quad \mathrm{SAMN07257079}\left(\left[\mathrm{P}_{66614}\right][2,4,4]\right), \quad$ SAMN07257080 $\left(\left[\mathrm{P}_{66614}\right]\left[\mathrm{N}(\mathrm{CN})_{2}\right]\right)$, SAMN07257081 ([P 66614$][\mathrm{Bt}])$.

\subsubsection{DNA extraction}

After termination of the studies, one soil sample (20 $\mathrm{g}$ of soil) from each replicate was collected. Afterwards, all samples belonging to the same set were homogenized and three $10 \mathrm{~g}$ 
subsamples were collected from each set. These subsamples were stored at $-80{ }^{\circ} \mathrm{C}$ until further processing (less than two weeks). Each subsample was subjected to extraction of total DNA and further analyzes separately and the data obtained for each set of subsamples was combined. Total DNA was extracted from $500 \mathrm{mg}$ of each soil using Genomic Mini AX Soil kit (A\&A Biotechnology) according to manufacturer's instruction. Extracted DNA were quantified using Quant-iT HS ds.-DNA assai kit (Invitrogen) on Qubit2 fluorometer; $2 \mu 1$ of extracts were examined on a $0.8 \%$ agarose gel.

\subsubsection{Biodiversity assessment}

For PCR amplification and calculation of OTU abundance and Shannon's index we followed the procedure presented in Lawniczak et al. (2016). Briefly, we targeted Region IV of bacterial 16S RNA gene amplified using a set of primers with Illumina adapters, followed by sequencing using primers as described in Caporaso et al. (2012). The sequencing was done using paired-end (2x250) MiSeq Reagent Kits v2 (Illumina, USA). For processing of the sequencing data, as in Lawniczak et al. (2016), we used CLC Genomic Workbench 8.5 and CLC Microbial Genomics Module 1.2. (Qiagen, USA), followed by clustering of the sequencing reads against the SILVA v119 99\% 16S rRNA gene database (July 24, 2014, Quast et al. 2013). OTU abundance and Shannon's index were calculated for rarefaction analysis with a depth of 100000 sequences per sample.

\subsection{Biodegradation in soil}

The biodegradation experiments in soil were carried out in sealed 1-L glass bottles as described in section.2.4. Therefore, the set-up for the tests consisted of 18 samples contaminated with ILs (i.e. 3 samples for each IL), 3 additional samples for monitoring of the soil moisture and 3 control samples (spiked only with methanol, which was then evaporated with nitrogen). The microcosms were incubated at $20^{\circ} \mathrm{C}$ for 100 days. After 100 days, one soil portion $(0.5 \mathrm{~g})$ from each bottle contaminated with IL was subjected to three-step ultrasound assisted extraction with methanol ( $3 \times 1 \mathrm{~mL})$ and analyzed by HPLC-MS.

In order to include sorbed fraction of the used ILs onto soil matrix during calculation of the ions residual masses, additional control tests with sterilized soil (to inhibit biodegradation) contaminated with ILs were performed. First, the urban park soil was divided into aliquots of $30 \mathrm{~g}$, frozen, placed in sealed polyethylene bags and irradiated at 40,000 grey using a ${ }^{192}$ Ir source (Alef and Nannipleri 1995). Afterwards, a methanol solution $(5 \mathrm{~mL})$ of 
selected IL was added to $10 \mathrm{~g}$ of sterilized soil. Next, methanol was evaporated and untreated sterilized soil in the amount of 90 grams was added. Finally, samples were mixed vigorously. The set-up for the sorption tests consisted of 18 samples contaminated with ILs (i.e. 3 samples for each IL) and 1 additional sample for monitoring of the soil moisture. All of the samples contained the base traps to provide constant moisture content of the soil (equal to $18 \pm 2 \%$ ). After 100 days of incubation at $20^{\circ} \mathrm{C}$ under sterile conditions, $0.5 \mathrm{~g}$ portion of soil from each replicate was subjected to a three-step ultrasound assisted extraction with methanol $(3 \times 1$ $\mathrm{mL}$ ) and analyzed by HPLC-MS to determine the fraction of ILs that was not permanently sorbed onto soil matrix. During the calculation of ions residual masses, it was assumed that the value of sorbed fraction is constant and does not change over time. Moreover, we assumed linear relationship between sorption and concentration of the used ILs (although in reality the relationship is not linear), which is a simplified, but still relevant assumption for organic compounds (Moyo et al. 2014). The recovery efficiency of the extraction of the ILs from the soil matrix dependent on the used ILs and reached (with respect to both cation and anion) $99 \%$ for $\left[\mathrm{P}_{6661} 4\right][2,4,4], \quad 89 \%$ for $\left[\mathrm{P}_{66614}\right][\mathrm{Br}], \quad 89 \%$ for $\left[\mathrm{P}_{66614}\right]\left[\mathrm{Ntf}_{2}\right], \quad 86 \%$ for $\left[\mathrm{P}_{66614}\right]\left[\mathrm{N}(\mathrm{CN})_{2}\right], 70 \%$ for $\left[\mathrm{P}_{66614}\right][3 \mathrm{AT}]$ and $73 \%$ for $\left[\mathrm{P}_{66614}\right][\mathrm{Bt}]$.

\subsection{HPLC-MS analysis}

For HPLC-MS analysis of residual ions can we followed the procedure of Sydow et al. (2015). Briefly, three $1 \mathrm{~mL}$ soil extracts (all three obtained via three-step extraction of each soil sample) were combined, filtered through a $0.2 \mu \mathrm{m}$ PTFE syringe filter and diluted with methanol : water solution $(80: 20 \mathrm{v} / \mathrm{v})$. The HPLC-MS analyses were performed with the UltiMate 3000 RSLC chromatograph from Dionex (Sunnyvale, CA, USA). Five $\mu$ L samples were injected into a Hypersil GOLD column (100 mm $2.1 \mathrm{~mm}$ I.D.; $1.9 \mu \mathrm{m})$ with a $2.1 \mathrm{~mm}$ I.D. pre-filter cartridge $(0.2 \mu \mathrm{m})$ from Thermo Scientific (Waltham, MA, USA). The mobile phase consisted of $5 \times 10^{-3} \mathrm{~mol} \mathrm{~L}^{-1}$ ammonium acetate in water (phase A) and methanol (phase B) at a flow rate of $0.2 \mathrm{~mL} \mathrm{~min}^{-1}$.

\subsection{Evolution of $\mathrm{CO}_{2}$ from the microcosms}

The $\mathrm{CO}_{2}$ evolution tests were carried out in the same sealed 1-L glass bottles as described in section 2.4. Overall, 18 soil samples contaminated with ILs (i.e. 3 samples for each IL), 3 soil samples for moisture monitoring and 3 control samples (containing $100 \mathrm{~g}$ of park soil spiked with methanol, which was then evaporated with nitrogen) were prepared. The controls were 
prepared to investigate the background respiration of the used park soil. The amount of emitted $\mathrm{CO}_{2}$ from the microcosms was determined by measuring $\mathrm{CO}_{2}$ content in a base trap ( $10 \mathrm{~mL}$ of $0.75 \mathrm{M} \mathrm{NaOH}$ in a $20-\mathrm{mL}$ vial) placed in the microcosms (as described by Szulc et al. (2014) and Sydow et al. (2015)). Briefly, titration of the diluted $\mathrm{NaOH}$ and $\mathrm{Na}_{2} \mathrm{CO}_{3}$ solution from the trap was done with $0.1 \mathrm{M} \mathrm{HCl}$ using an automatic titrator (Metrohm titroprocessor 686). The content of the base traps was replaced with fresh $\mathrm{NaOH}$ solution after each measurement.

\subsection{Statistical analysis}

All experiments were carried out in triplicates. Each error margin range represents standard errors of the mean (SEM). Analysis of variance (at $\alpha=0.05$ ) in Statistica 6.0 was employed for statistical comparisons.

\section{Results and Discussion}

\subsection{Biodegradation of ionic liquids and evolution of $\mathrm{CO}_{2}$ from soil microcosms}

The $\mathrm{EC}_{50}$ values (corrected for sorbed fraction in soil) reached $3010 \mathrm{mg} \mathrm{kg}^{-1}(0.0323$ [M]) for $\left[\mathrm{P}_{66614}\right][\mathrm{Br}], 3290 \mathrm{mg} \mathrm{kg}^{-1}(0.0237[\mathrm{M}])$ for $\left[\mathrm{P}_{66614}\right][2,4,4], 3540 \mathrm{mg} \mathrm{kg}^{-1}(0.0258[\mathrm{M}])$ for $\left[\mathrm{P}_{66614}\right]\left[\mathrm{Ntf}_{2}\right], 3590 \mathrm{mg} \mathrm{kg}^{-1}(0.0332[\mathrm{M}])$ for $\left[\mathrm{P}_{66614}\right][\mathrm{Bt}], 3840 \mathrm{mg} \mathrm{kg}^{-1}(0.0377[\mathrm{M}])$ for $\left[\mathrm{P}_{66614}\right][3 \mathrm{AT}]$ and $3960 \mathrm{mg} \mathrm{kg}^{-1}(0.0401[\mathrm{M}])$ for $\left[\mathrm{P}_{66614}\right]\left[\mathrm{N}(\mathrm{CN})_{2}\right]$.

As can be seen in Figure 1, after 100 days of incubation, residual ions (both cation and anion) were detected in all contaminated soil samples (bromide anion was not investigated). The presence of different anions had significant influence on the residual amount of the [ $\left.\mathrm{P}_{66614}\right]$ cation. The lowest amount of cation residue was observed when the anion was $[\mathrm{Br}]$ $(9 \%)$ and $[2,4,4](11 \%)$. On the other hand, the highest amount of cation residue was observed when the anion was $\left[\mathrm{N}(\mathrm{CN})_{2}\right](60 \%)$. For other soil samples spiked with ILs, the residual amounts of cations were as follows: $31 \%\left(\left[\mathrm{P}_{66614}\right][3 \mathrm{AT}]\right), 42 \%\left(\left[\mathrm{P}_{66614}\right][\mathrm{Bt}]\right)$ and $47 \%$ $\left(\left[\mathrm{P}_{66614}\right]\left[\mathrm{Ntf}_{2}\right]\right)$. Moreover, the lowest amount of anion residue was observed in the case of $[2,4,4](12 \%)$ and the highest amount of anion residue was detected in samples contaminated with $\left[\mathrm{P}_{66614}\right]\left[\mathrm{N}(\mathrm{CN})_{2}\right](46 \%$ of anion residue). The amount of other residual anions were as follow: $38 \%$ ([3AT]), $41 \%$ ([Bt]) and $26 \%\left(\left[\mathrm{Ntf}_{2}\right]\right)$.

In order to elucidate mechanism determining the shape of community structure and biodiversity changes we carried out biodegradation and $\mathrm{CO}_{2}$ evolution experiments. The $\mathrm{CO}_{2}$ evolution curves for all the used ILs are presented in Figure 2. At the end of the experiment, 
the highest amount of emitted $\mathrm{CO}_{2}(29.8 \mathrm{mmol})$ was observed in the sample containing $\left[\mathrm{P}_{66614}\right][\mathrm{Br}]$. The emission of $\mathrm{CO}_{2}$ in other samples did not differ significantly from the emission observed in the case of control sample $(25.7 \mathrm{mmol})$ without any ILs addition. Furthermore, in the case of $\left[\mathrm{P}_{66614}\right]\left[\mathrm{N}(\mathrm{CN})_{2}\right]$ (i.e. IL that was primarily degraded to the lowest extent) respiration of the soil was significantly lower than in control sample, reaching 22.6 mmol of emitted $\mathrm{CO}_{2}$. The obtained results showed that the studied ILs generally did not significantly inhibit the respiration activity of soil microbiota.

The biodegradation results showed that biodegradation of the studied phosphoniumbased ILs was different depending on the attached anion. The lowest amount of $\left[\mathrm{P}_{66614}\right]$ cation residue was observed in the case of ILs with inorganic [Br] anion, which surely did not influence the biodegradation of the cation. The lowest amount of anion residue was observed in the case of $[2,4,4]$ anion, which consists of two 2,4,4-trimethylpentyl chains. The $[2,4,4]$ anion is structurally similar to branched alkanes and may potentially be utilized by iso-alkanes degraders, which were likely present in the studied soil (Sydow et al. 2016). Previous studies confirmed that branched alkanes utilizers are present in soils permanently polluted by petroleum hydrocarbons and may induce growth of some bacterial taxa (Sydow et al. 2016). The observed rapid biodegradation of $[2,4,4]$ anion may also explain its low inhibitory effect toward biodegradation of cation. Nevertheless, the $\mathrm{CO}_{2}$ evolution results did not confirm full mineralization of the $\left[\mathrm{P}_{66614}\right][2,4,4]$, as the amount of emitted $\mathrm{CO}_{2}$ was not statistically different from the control. Therefore, similarly to other studied ILs, $\left[\mathrm{P}_{66614}\right][2,4,4]$ was most probably transformed by the microbial community to metabolic intermediates. The metabolic pathway associated with transformation of the molecules similar to branched alkanes are less known than those for linear alkanes, but may involve an $\omega$-oxidation of the compound with formation of dicarboxylic acids in the first step, leading to shorter-chained products (Stolte et al. 2008; Rojo, 2010). In general, the phosphonium-based ILs with antifungal properties are not expected to be readily degraded by indigenous soil microbial communities inhabiting soils even in longer periods of time (i.e. 300 days) (Sydow et al. 2015). Also Deive et al. (2011) observed low biodegradability (degradation rate lower than $25 \%$, in many cases equal to $0 \%$ ) of several 1-ethyl-3-methylimidazolium- and cholinium-based ILs in 2-months test conducted with the use of microbial communities isolated from the industrial and salt marsh soil and cultivated on peptone solution.

Only soil samples spiked with $\left[\mathrm{P}_{66614}\right][\mathrm{Br}]$ were characterized by significantly higher $\mathrm{CO}_{2}$ evolution compared to the control. This indicates none or marginal mineralization of the 
studied ILs in urban soil. Following the approach presented in Horel and Schiewer (2011) and Sydow et al. (2015), a carbon mass balance was performed in order to estimate the mineralization of primarily degraded $\left[\mathrm{P}_{66614}\right][\mathrm{Br}]$. Assuming a yield of $0.4 \mathrm{~g}$ of microbial carbon per $1 \mathrm{~g}$ of IL carbon, it was calculated that approximately $42 \%$ of the primarily degraded $\left[\mathrm{P}_{66614}\right][\mathrm{Br}]$ was mineralized. This corresponds to $31 \%$ mineralization of the total compound. For the majority of the used ILs, the measured $\mathrm{CO}_{2}$ evolution was not statistically different as compared to control, which is in agreement with our previous study dedicated to biodegradability of other phosphonium- and ammonium-based ILs (Sydow et al. 2015). In that study, it was observed that the only mineralized compound was $\left[\mathrm{P}_{66614}\right][\mathrm{Cl}]-$ the only IL with inorganic anion and a similar chemical composition to $\left[\mathrm{P}_{66614}\right][\mathrm{Br}]$ (both are composed of halide anion). Although it is possible that the presence of complex organic anions attached to $\left[\mathrm{P}_{66614}\right]$ cation may have inhibited mineralization of the cation, and simultaneously, the whole compound, the opposite mechanism suggesting the negative influence of cation on biodegradation of organic anions cannot be excluded. Although the presence of long alkyl chains (as in the case of $\left[\mathrm{P}_{66614}\right]$ cation) may facilitate biodegradation of the whole compound, it was previously observed that such ions may simultaneously be more toxic than homologues with shorter chains (Stolte et al. 2011).

\subsection{Structure of soil bacteria after exposure to ionic liquids}

Figure $3 \mathrm{a}$ shows the contribution of dominant classes identified within soil microbial community after exposure to either of the studied ILs at sub-lethal concentrations. The obtained results indicate that the studied phosphonium-based ILs had significant influence on the structure of soil microbial community as the contribution of dominant classes changed after 100-day exposure. In four out of six soil samples spiked with ILs, the contribution of Alphaproteobacteria increased with the highest increase (by 24\%) was observed for $\left[\mathrm{P}_{66614}\right]\left[\mathrm{N}(\mathrm{CN})_{2}\right]$. The contribution of Gammaproteobacteria increased only in case of $\left[\mathrm{P}_{66614}\right]\left[\mathrm{N}(\mathrm{CN})_{2}\right]$ (by 5\%), while the Bacilli class increased in case of $\left[\mathrm{P}_{66614}\right][2,4,4]$ and $\left[\mathrm{P}_{66614}\right]\left[\mathrm{Ntf}_{2}\right]$ (by up to $10 \%$ ). The increase of contribution of Clostridia class was observed for $\left[\mathrm{P}_{66614}\right][\mathrm{Bt}]$ (by 7\%), $\left[\mathrm{P}_{66614}\right]\left[3 \mathrm{AT}\right.$ (by 2\%)] and $\left[\mathrm{P}_{66614}\right][\mathrm{Br}]$ (by 1\%), while the contribution of Deltaproteobacteria increased only in case of $\left[\mathrm{P}_{66614}\right][\mathrm{Bt}]$ (by 5\%), Betaproteobacteria class slightly increased its contribution in case of all samples with exception of $\left[\mathrm{P}_{66614}\right]\left[\mathrm{Ntf}_{2}\right]$. The contribution of Sphingobacteria class increased only in samples spiked with $\left[\mathrm{P}_{66614}\right][3 \mathrm{AT}]$ (by 12\%) and $\left[\mathrm{P}_{66614}\right][2,4,4]$ (by 8\%). On the other hand, 
the contribution of Actinobacteria and Planctomycetia class decreased by 1 to $7 \%$ (depending on the ILs) in all samples compared to control.

Figure $3 \mathrm{~b}$ shows the contribution of the five most abundant bacterial families identified in soils spiked with particular ILs and control. The structure of the microbial community changed significantly in all of the studied samples spiked with ILs, as new families became dominant within microbial community. The most dominant microbial families detected in control sample were Xanthomonodaceae (most abundant), followed by Planctomycetaceae, Bacillaceae, Caulobacteraceae and Hyphomicrobioaceae. In the case of soil samples spiked with $\left[\mathrm{P}_{66614}\right]\left[\mathrm{N}(\mathrm{CN})_{2}\right],\left[\mathrm{P}_{66614}\right]\left[\mathrm{Ntf}_{2}\right]$ and $\left[\mathrm{P}_{66614}\right][2,4,4]$ more than $50 \%(\mathrm{p}$ $=0.015)$ of the contribution was represented by five most abundant bacterial families. By contrast, in the case of soil samples spiked with other ILs, the dominant families represented no more than $35 \%$ of all identified families. The contribution of Xanthomonoddaceae family (the most abundant in control sample) decreased in all soil samples spiked with ILs, but its dominance was maintained in samples spiked with $\left[\mathrm{P}_{66614}\right][\mathrm{Br}]$ and $\left[\mathrm{P}_{66614}\right]\left[\mathrm{N}(\mathrm{CN})_{2}\right]$. Compared to control sample, the contribution of bacterial family belonging to Sphingomonadaceae became significant in majority of the samples contaminated with ILs (only in case of $\left[\mathrm{P}_{66614}\right][\mathrm{Bt}]$ this family was not detected as top five abundant). Moreover, with respect to soil samples contaminated with $\left[\mathrm{P}_{66614}\right]\left[\mathrm{N}(\mathrm{CN})_{2}\right]$ and $\left[\mathrm{P}_{66614}\right]\left[\mathrm{Ntf}_{2}\right]$, the most abundant genus was Sphingomonas, which represented $13.70(\mathrm{p}=0.012)$ and $17.57 \%(\mathrm{p}=$ 0.008) of all identified genera, respectively (data not shown). Also, in the case of the soil samples spiked with $\left[\mathrm{P}_{66614}\right][2,4,4]$, a significant percent of contribution was represented by Sphingomonas $(6.41 \%, \mathrm{p}=0.027)$ and Pseudomonas $(6.72 \%, \mathrm{p}=0.014)$. In general, in the case of all studied samples spiked with ILs the contribution of Sphingomonas and Pseudomonas genera was higher compared to the control sample (Sphingomonas: $1.46 \%$ for control; $1.83 \%$ for $\left[\mathrm{P}_{66614}\right][\mathrm{Bt}], 2.78 \%$ for $\left[\mathrm{P}_{66614}\right][3 \mathrm{AT}], 3.09 \%$ for $\left[\mathrm{P}_{66614}\right][\mathrm{Br}], 6.41 \%$ for $\left[\mathrm{P}_{66614}\right][2,4,4], 17.57 \%$ for $\left[\mathrm{P}_{66614}\right]\left[\mathrm{Ntf}_{2}\right]$ and $13,70 \%$ for $\left[\mathrm{P}_{66614}\right]\left[\mathrm{N}(\mathrm{CN})_{2}\right]$; Pseudomonas: $0.05 \%$ for control; $0.79 \%$ for $\left[\mathrm{P}_{66614}\right][\mathrm{Bt}], 3.62 \%$ for $\left[\mathrm{P}_{66614}\right][3 \mathrm{AT}], 1.12 \%$ for $\left[\mathrm{P}_{66614}\right][\mathrm{Br}]$, $6.72 \%$ for $\left[\mathrm{P}_{66614}\right][2,4,4], 2.98 \%$ for $\left[\mathrm{P}_{66614}\right]\left[\mathrm{Ntf}_{2}\right]$ and $0.49 \%$ for $\left.\left[\mathrm{P}_{66614}\right]\left[\mathrm{N}(\mathrm{CN})_{2}\right]\right)$.

The Shannon's diversity estimates differed significantly $(\mathrm{p}<0.05)$ among control and the treatments, but also among some of the treatments, with a mean Shannon's index value of 1.33 (Table 2). Moreover, the highest value of Shannon's index was obtained for control soil. Additionally, the mean value of the observed OTU's was also significantly different among control and ILs treated soils and reached a maximum value for control soil (1399) (Table 2). 
The lowest value of OTU's and Shannon's index was determined for $\left[\mathrm{P}_{66614}\right][2,4,4]$ (OTU's $=$ 965, Shannon's index $=0.73$ ). In general, the introduction of the studied ILs contributed to significant reduction of the microbial biodiversity in soil. The PCA plot of weighted Unifrac distances indicate that the bacterial community structure changed significantly $(p=0.017)$ upon treatment with the studied ILs compared to control soil (Fig. 4). There were no significant differences between microbial structures of soils treated with $\left[\mathrm{P}_{66614}\right][3 \mathrm{AT}]$ and $\left[\mathrm{P}_{66614}\right][\mathrm{Bt}](\mathrm{p}=0.71)$, and between $\left[\mathrm{P}_{66614}\right]\left[\mathrm{Ntf}_{2}\right]$ and $\left[\mathrm{P}_{66614}\right]\left[\mathrm{N}(\mathrm{CN})_{2}\right](\mathrm{p}=0.14)$.

In contrast to the results obtained in this study, Lawniczak et al. (2016) did not observe an effect of the herbicidal ionic liquids on biodiversity (both OTU's and Shannon's index were not significantly different from the control). However, similarly to our study, they observed that the structure of the community (assessed using Illumina NGS) was significantly affected (on the phylum level) by the exposure to herbicidal ILs. This difference may be explained by either shorter exposure time (100 days in this study, 28 days in Ławniczak et al. (2016)) not allowing occurrence of significant changes in biodiversity, or differences in applied ILs concentration and differences in initial biodiversity of the studied soils (control Shannon's index in this study was 1.75, while control Shannon's index in Ławniczak et al. (2016) was 4.95). A higher biodiversity is usually associated with higher resistance to different perturbations (Isbell et al. 2015). Deive et al. (2011) also observed a decrease in biodiversity of microbial communities isolated from the salt marsh and industrial soils exposed to various imidazolium- and cholinium-based ILs. The authors observed higher survival of microbial strains isolated from industrial soils, which were contaminated in the past by petroleum hydrocarbons. Also Sun et al. (2017) observed a significant decrease in biodiversity and alternation of the structure of soil microbial community exposed to 1-octyl-3methylimidazolium tetrafluoroborate for 40 days. On the other hand, Guo et al. (2015) observed a significant decrease in biodiversity of soil microbial community only in higher concentrations of the alkyl-imidazolium-based ionic liquid with chloride anion.

\subsection{Explaining changes in community structure and decrease in biodiversity}

Basing on the genetic assay and biodegradation and $\mathrm{CO}_{2}$ evolution experiments, it is hypothesized that decrease in biodiversity is explained by a combination of two factors (i) a toxic effect of the phosphonium-based ILs or their metabolites towards non-resistant microbial taxa within the community, and/or (ii) an emergence of few ILs-degrading taxa, which outcompeted the other unable to utilize ILs or their metabolites. In the first case, the 
contribution of more resistant species should increase after the perturbation. Gram-negative bacteria are generally more resistant to toxic organic compounds, such as organic solvents or antibiotics, which may be explained by their different structure resulting in the presence of the efflux pump systems and outer cell membranes (Vermuë et al. 1993; Heipieper et al. 2007; Heipieper and Martinez 2010; Stancu and Grifoll, 2011). As observed, the contribution of two Gram-negative genera - Pseudomonas and Sphingomonas - increased in all samples spiked with ILs, which may support the first hypothesis regarding the toxicity. Some of the studied phospohonium-based ILs were found to be toxic to single bacterial species (especially these containing halide anions) (Cieniecka-Rosłonkiewicz et al. 2005). However, it was observed that the contribution of Gram-positive Geobacillus genus also increased in all soil samples and became dominant in the samples spiked with $\left[\mathrm{P}_{66614}\right][2,4,4]$ (contribution equal to $15.61 \%$ ) and $\left[\mathrm{P}_{66614}\right]\left[\mathrm{Ntf}_{2}\right]$ (contribution equal to $15.08 \%$ ). Yet, only one IL, $\left[\mathrm{P}_{66614}\right]\left[\mathrm{N}(\mathrm{CN})_{2}\right]$, exhibited significantly lower $\mathrm{CO}_{2}$ evolution compared to control, indicating, in general, none or low inhibition of the microbial activity in presence of the studied ILs. Thus, the observed increase in abundance of bacteria belonging to the families Sphingomonadaceae and Pseudomonadaceae, which consist of well-known hydrocarbon-degrading genera may support the latter hypothesis, since all of the studied ILs consisted of [ $\left.\mathrm{P}_{66614}\right]$ cation with long alkyl chains structurally similar to $n$-alkanes. Especially the genera Sphingomonas and Pseudomonas are known for their ability to degrade various petroleum hydrocarbons, but also other toxic compounds (White et al. 1996; Whyte et al. 1997). The highest reduction of biodiversity was observed in soil samples spiked with $\left[\mathrm{P}_{66614}\right][\mathrm{Br}]$ and $\left[\mathrm{P}_{66614}\right][2,4,4]-$ compounds that were degraded to the highest extent. This may suggest that an efficient biodegradation of ILs could induce the greater structural changes within microbial community and the emergence of ILs-degraders. Guo et al. (2015) suggested that changes in biodiversity of soil microbial community exposed to ILs may be caused by the intensified growth of some microbial strains able to degrade new carbon source such as ILs. The presence of previously unavailable carbon sources often induces the growth of specialists (also called r-strategists) and decline of generalists (K-strategists) (Ciric et al. 2010; Sydow et al. 2016). Thus, the observed reduction in biodiversity should be rather explained by the primary biodegradation of ILs resulting from an emergence of ILs-degrading taxa within the microbial community.

\section{Conclusions}


443 We showed that when supplied at sub-lethal concentrations, the studied phosphonium-based 444 ILs could be a stress factor for soil microbial communities and impact their structure 445 diversity, especially by increasing the abundance of well-known hydrocarbon-degrading genera such as Sphingomonas and Pseudomonas. Future studies should focus on determination of possible ILs metabolites produced by environmental microbial consortia and the effect of ILs on soil microbial communities at environmentally relevant concentrations.

\section{Acknowledgements}

This study was financed by funds granted by the National Science Centre in Poland conferred on the basis of the decision nr DEC-2011/03/B/NZ9/00731.

\section{References}

Adeboye MKA, Bala A, Osunde AO, Uzoma AO, Odofin AJ, Lawal BA (2011) Assessment of soil quality using soil organic carbon and total nitrogen and microbial properties in tropical agroecosystems. Agr Sci 2:34-40.

An YJ, Kim YM, Kwon YI, Jeong SW (2004) Combined effect of copper, cadmium, and lead upon Cucumis sativus growth and bioaccumulation. Sci Total Environ 326:857-863.

Alef K, Nannipleri P (1995) Methods in Applied Soil Microbiology and Biochemistry. Academic Press, San Diego, USA.

Borkowski A, Ławniczak Ł, Cłapa T, Narożna D, Selwet M, Pęziak D, Markiewicz B, Chrzanowski $€$ (2016) Different antibacterial activity of novel theophylline-based ionic liquids - Growth kinetic and cytotoxicity studies. Ecotoxicol Environ Saf 130:54-64.

Caporaso JG, Lauber CL, Walters WA, Berg-Lyons D, Huntley J, Fierer N, Owens SM, Betley J, Fraser L, Bauer M, Gormley N, Gilbert JA, Smith G, Knight R (2012) Ultra-highthroughput microbial community analysis on the Illumina HiSeq and MiSeq platforms. ISME J 6:1621-1624. 
477

478

479

480

481

482

483

484

485

486

487

488

489

490

491

492

493

494

495

496

497

498

499

500

501

502

503

504

Cieniecka-Rosłonkiewicz A, Pernak J, Kubis-Feder J, Ramani A, Robertson AJ, Seddon KR (2005) Synthesis, anti-microbial activities and anti-electrostatic properties of phosphoniumbased ionic liquids. Green Chem 7:855-862.

Ciric L, Philip JC, Whiteley AS (2010) Hydrocarbon utilization within a diesel-degrading bacterial consortium. FEMS Microbiol Lett 303:116-122.

Coleman D, Gathergood N (2010) Biodegradation studies of ionic liquids. Chem Soc Rev 39:600-637.

Cvjetko Bubalo M, Radošević K, Radojčić Redovniković I, Halambek J, Gaurina Srček V (2014) A brief overview of the potential environmental hazards of ionic liquids. Ecotoxicol Environ Saf 99:1-12.

Deive FJ, Rodriguez A, Varela A, Rodrigues C, Leitảo MC, Houbraken JAMP, Pereiro AB, Longo MA, Sanromản MA, Samson RA, Rebelo LPN, Silva Pereira C (2011) Impact of ionic liquids on extreme microbial biotypes from soil. Green Chem 13:687-696.

Ferlin N, Courty M, Gatard S, Spulak M, Quilty B, Beadham I, Ghavre M, Haiß A, Kümmerer K, Gathergood N, Bouquillon S (2013a) Biomass derived ionic liquids: synthesis from natural organic acids, characterization, toxicity, biodegradation and use as solvents for catalytic hydrogenation processes. Tetrahedron 69:6150-6161.

Ferlin N, Courty M, Van Nhien AN, Gatard S, Pour M, Quilty B, Ghavre M, Haiß A, Kümmerer K, Gathergood N, Bouquillon S (2013b) Tetrabutylammoniumprolinate-based ionic liquids: a combined asymmetric catalysis, antimicrobial toxicity and biodegradation assessment. RSC Adv 3:26241-26251.

Fraser KJ, MacFarlane DR (2009) Phosphonium-Based Ionic Liquids: An Overview. Aust. J. Chem. 62:309-321. 
505 Guo P, Zhu L, Wang J, Wang J, Liu T (2015) Effects of alkyl-imidazolium ionic liquid $506[\mathrm{Omim}] \mathrm{Cl}$ on the functional diversity of soil microbial communities. Environ Sci Pollut Res 22:9059-9066.

508

509

Heipieper H.J, Martínez P. (2010) Toxicity of hydrocarbons to microorganisms. In: Timmis

510

511

512

513

514

515

516

517

518

519

520

521

522

523

524

525

526

527

528

529

530

531

532

533

534

535

536

K.N. (Ed.) Handbook of Hydrocarbon and Lipid Microbiology. Springer, Berlin, Heidelberg.

Vol. 2, Part 9, pp. 1565-1573.

Heipieper H.J, Neumann G, Cornelissen S, Meinhardt F. (2007) Solvent-tolerant bacteria for biotransformations in two-phase fermentation systems. Appl Microbiol Biotechnol 74:961973.

Horel A, Schiewer S (2011) Influence of constant and fluctuating temperature on biodegradation rates of fish biodiesel blends contaminating Alaskan sand. Chemosphere $83: 652-60$.

Isbell F, Craven D, Connolly J, Loreau M, Schmid B, Beierkuhnlein C, Bezemer T.M, Bonin C, Bruelheide H, de Luca E, Ebeling A, Griffin J.N, Guo Q, Hautier Y, Hector A, Jentsch A, Kreyling J, Lanta V, Manning P, Meyer S.T, Mori A.S, Naeem S, Niklaus P.A, Polley H.W, Reich P.B, Roscher C, Seabloom E.W, Smith M.D, Thakur M.P, Tilman D, Tracy B.F, van der Putten W.H, van Ruijven J, Weigelt A, Weisser W.W, Wilsey B.J, Eisenhauer N (2015) Biodiversity increases the resistance of ecosystem productivity to climate extremes. Nature 526:574-577.

Jordan A, Gathergood N (2015) Biodegradation of ionic liquids - a critical review. Chem Soc Rev 44:8200-8237.

Ławniczak Ł, Syguda A, Borkowski A, Cyplik P, Marcinkowska K, Wolko Ł, Praczyk T, Chrzanowski Ł, Pernak J (2016) Influence of oligomeric herbicidal ionic liquids with MCPA and Dicamba anions on the community structure of autochthonic bacteria present in agricultural soil. Sci Total Environ 563-564:247-255. 
Liwarska-Bizukojc E, Gendaszewska D (2013) Removal of imidazolium ionic liquids by microbial associations: Study of the biodegradability and kinetics. J Biosci Bioeng 115:7175.

Modelli A, Sali A, Galletti P, Samorì C (2008) Biodegradation of oxygenated and nonoxygenated imidazolium-based ionic liquids in soil. Chemosphere 73:1322-1327.

Moyo F, Tandlich R, Wilhelmi BS, Balaz S (2014) Sorption of hydrophobic organic compounds on natural sorbents and organoclays from aqueous and non-aqueous solutions: A mini-review. Int J Environ Res Public Health 11:5020-5048.

Mrozik W, Kotłowska A, Kamysz W, Stepnowski P (2012) Sorption of ionic liquids onto soils: Experimental and chemometric studies. Chemosphere 88:1202-1207.

Paterson E, Sim A (1999) Rhizodeposition and C-partitioning of Lolium perenne in axenic culture affected by nitrogen supply and defoliation. Plant Soil 216:155-164.

Peric B, Sierra J, Marti E, Cruãnas R, Garau MA, Arning J, Bottin-Weber U, Stolte S (2013) (Eco)toxicity and biodegradability of selected protic and aprotic ionic liquids. J Hazard Mater 261:99-105.

Pernak J, Borucka N, Walkiewicz F, Markiewicz B, Fochtman P, Stolte S, Steudte S, Stepnowski P (2011) Synthesis, toxicity, biodegradability and physicochemical properties of 4-benzyl-4-methylmorpholinium-based ionic liquids. Green Chem 13:2901-2910.

Petkovic M, Ferguson J, Bohn A, Trindade J, Martins I, Carvalho MB, Leitão MC, Rodrigues C, Garcia H, Ferreira R, Seddon KR, Rebelo LPN, Silva Pereira C (2009) Exploring fungal activity in the presence of ionic liquids. Green Chem 11:889-894.

Pham TPT, Cho CW, Yun YS (2010) Environmental fate and toxicity of ionic liquids: A review. Water Res 44:352-372. 
Piotrowska A, Syguda A, Wyrwas B, Chrzanowski Ł, Heipieper HJ (2017) Toxicity

570 evaluation of selected ammonium-based ionic liquid forms with MCPP and dicamba moieties on Pseudomonas putida. Chemosphere 167:114-119.

572

Plechkova NV, Seddon, KR (2007) Applications of ionic liquids in the chemical industry. The SILVA ribosomal RNA gene database project: improved data processing and web-based tools. Nucl Acids Res 41(D1):D590-D596.

579

580

Quijano G, Couvert A, Amrane A (2010) Ionic liquids: Applications and future trends in bioreactor technology. Biores Technol 101:8923-8930.

582

Rojo F (2010) Enzymes for aerobic degradation of alkanes. In: Timmis K.N. (Ed.) Handbook of Hydrocarbon and Lipid Microbiology. Springer, Berlin, Heidelberg. Vol. 1, p. 781-797.

Stancu M.M, Grifoll M (2011) Multidrug resistance in hydrocarbon-tolerant Gram-positive and Gram-negative bacteria. J Gen Appl Microbiol 57:1-18.

Stepnowski P (2005) Preliminary assessment of the sorption of some alkyl imidazolium cations as used in ionic liquids to soils and sediments. Aust J Chem 58:170-173.

Stolte S, Abdulkarim S, Arning J, Blomeyer-Nienstedt A.-K, Bottin-Weber U, Matzke M, identification of degradation products of 1-methyl-3- octylimidazolium chloride and electrochemical wastewater treatment of poorly biodegradable compounds. Green Chem. $10: 214-224$.

598 Stolte S, Steudte S, Igartua A, Stepnowski P (2011) The biodegradation of ionic liquids e the view from a chemical structure perspective. Curr. Org. Chem. 15:1946-1973. 
601

602

603

604

605

606

607

608

609

610

611

612

613

614

615

616

617

618

619

620

621

622

623

624

625

626

627

628

629

630

631

632

Sun X, Zhu L, Wang J, Su B, Liu T, Zhang C, Gao C, Saho Y (2017) Toxic effects of ionic liquid 1-octyl-3-methylimidazolium tetrafluoroborate on soil enzyme activity and soil microbial community diversity. Ecotox Environ Safe 135:201-208.

Sydow M, Szczepaniak Z, Framski G, Staninska J, Owsianiak M, Szulc A, Piotrowska-Cyplik A, Zgoła-Grześkowiak A, Wyrwas B, Chrznowski Ł (2015) Persistence of selected ammonium- and phosphonium-based ionic liquids in urban park soil microcosms. Int Biodeterior Biodegradation 103:91-96.

Sydow M, Owsianiak M, Szczepaniak Z, Framski G, Smets B.F, Ławniczak Ł, Lisiecki P, Szulc A, Cyplik P, Chrzanowski $Ł$ (2016) Evaluating robustness of a diesel-degrading bacterial consortium isolated from contaminated soil. N Biotechnol 33:852-859.

Szulc A, Ambrożewicz D, Sydow M, Ławniczak Ł, Piotrowska-Cyplik A, Marecik R, Chrzanowski $\_$(2014) The influence of bioaugmentation and biosurfactant addition on bioremediation efficiency of diesel-oil contaminated soil: feasibility during field studies. J Environ Manage 132:121-128.

Ventura SPM, Marques CS, Rosatella AA,, Afonso CAM, Gonçalves F, Coutinho JAP (2012) Toxicity assessment of various ionic liquid families towards Vibrio fischeri marine bacteria. Ecotox Environ Safe 76:162-168.

Ventura SPM, Gurbisz M, Ghavre M, Ferreira FMM, Gonçalves F, Beadham I, Quilty B, Coutinho JAP, Gathergood N (2013) Imidazolium and pyridinium ionic liquids from mandelic acid derivatives: synthesis and bacteria and algae toxicity evaluation. ACS Sustainable Chem Eng 1:393-402.

Vermuë M, Sikkema J, Verheul A, Bakker R, Tramper J (1993) Toxicity of homologous series of organic solvents for the Gram-positive bacteria Arthrobacter and Nocardia sp. and the Gram-negative bacteria Acinetobacter and Pseudomonas sp. Biotechnol Bioeng 42:737-757. 
633 Walkiewicz F, Materna K, Kropacz A, Michalczyk A, Gwiazdowski R, Praczyk T, Pernak J 634 (2010) Multifunctional long-alkyl-chain quaternary ammonium azolate based ionic liquids.

635 New J Chem 34:2281-2289.

636

637

White DC, Sutton ST, Ringelberg DB (1996) The genus Sphingomonas: physiology and 638 ecology. Curr Opin Biotech 7:301-306.

639

640

Whyte LG, Bourbonnière L, Greer CW (1997) Biodegradation of petroleum hydrocarbons by 641 psychrotrophic Pseudomonas strains possessing both alkane (alk) and naphthalene (nah)

642 catabolic pathways. Appl Environ Microbiol 63:3719-3723.

643

644 You J, Wu G, Ren F, Chang Q, Yu B, Xue Y, Mu B (2016) Microbial community dynamics 645 in Baolige oilfield during MEOR treatment, revealed by Illumina MiSeq sequencing. Appl 646 Microbiol Biotechnol 100:1469-1478.

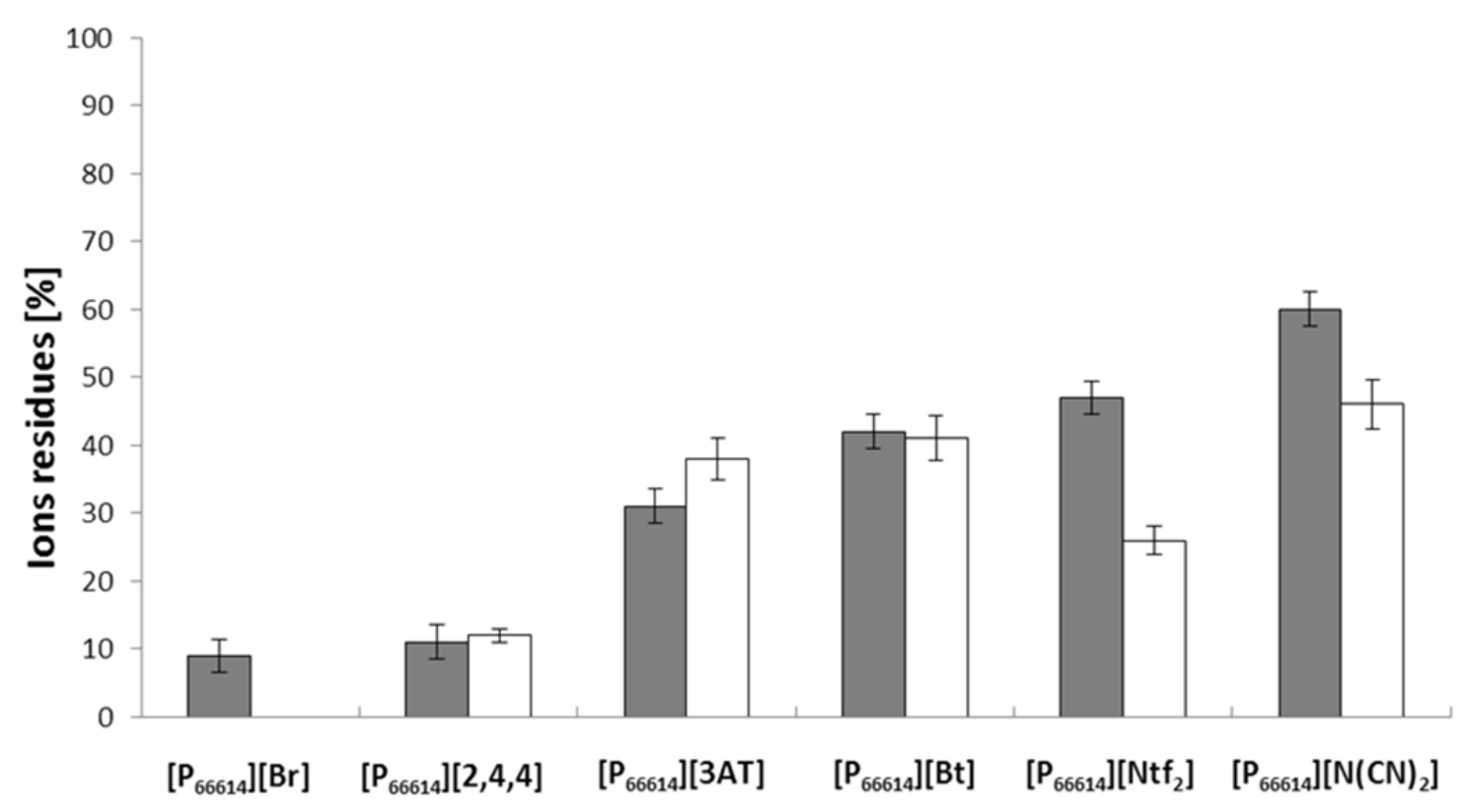

647

Fig. 1. The levels of ions residues of the selected phosphonium-based ILs after 100-day 649 experiment. Cation: grey bars, anions: white bars.

650 


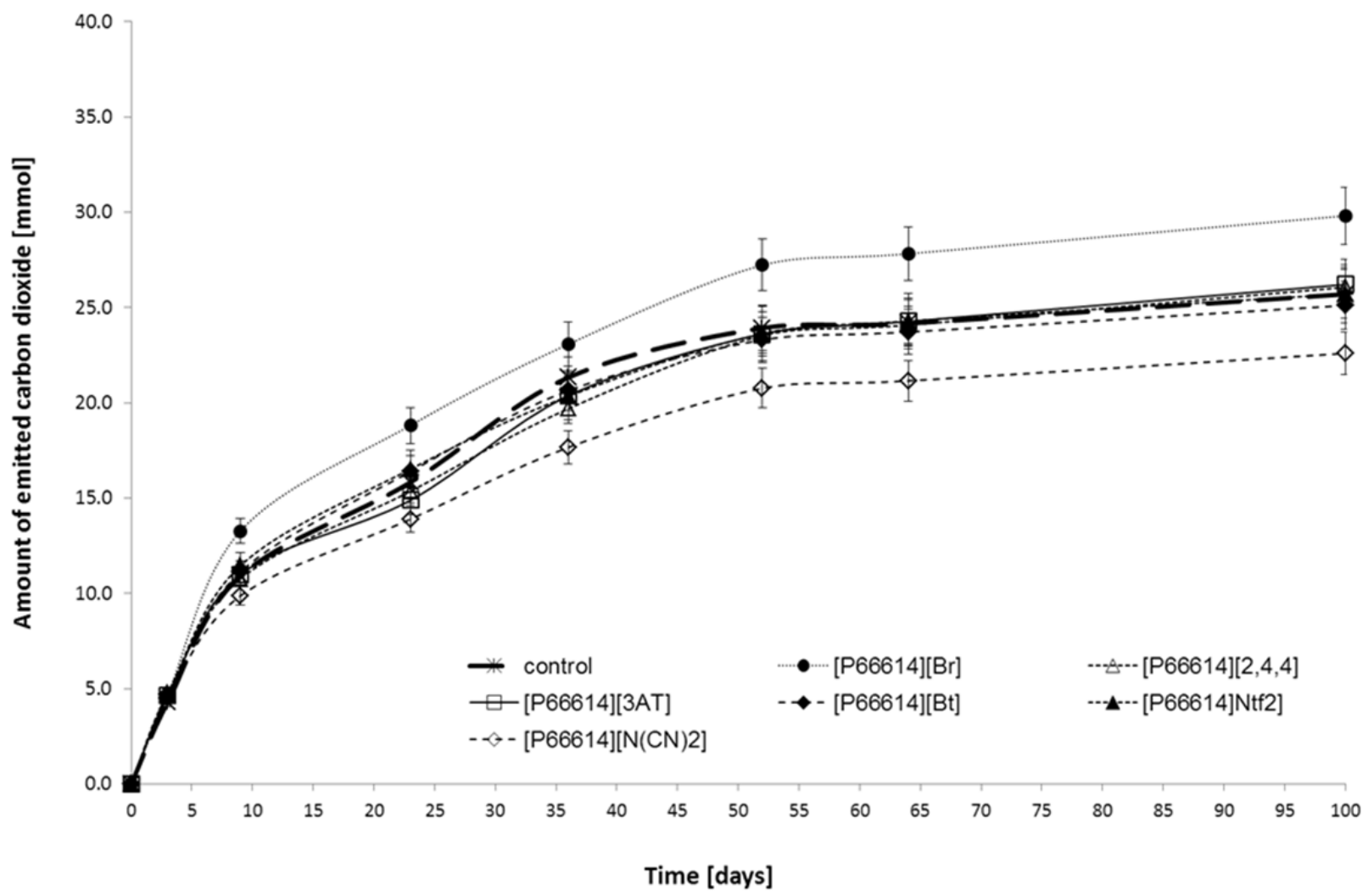

651

652 Fig. 2. The evolution of $\mathrm{CO}_{2}$ during the course of 100-day experiment.

653 


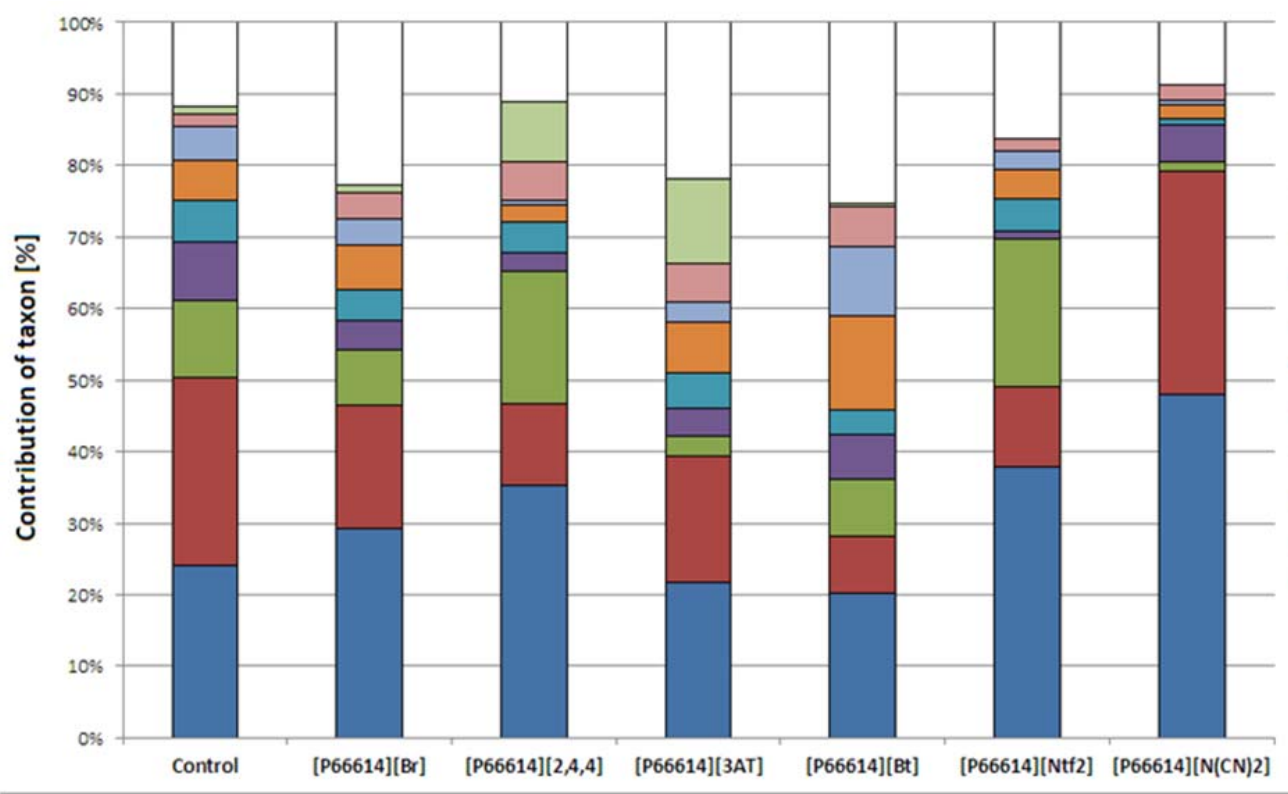

a

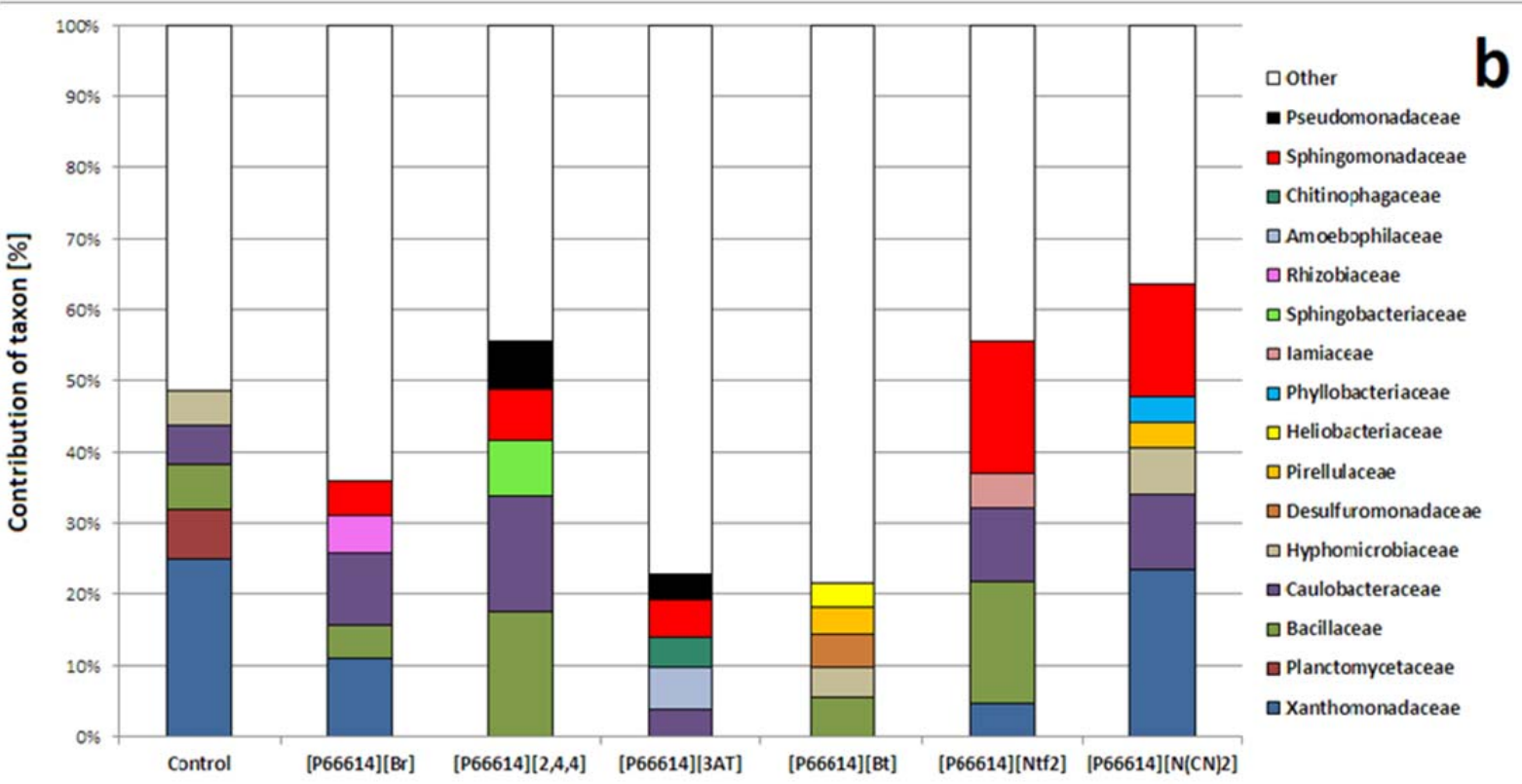

655 Fig. 3. The contribution of the most dominant microbial groups inhabiting urban park soil 656 spiked with phosphonium-based ILs after 100-day exposure, presented with respect to (a) 657 class, and (b) family taxonomic level (to facilitate the reading only five most dominant 658 families among each soil treatment were presented). 


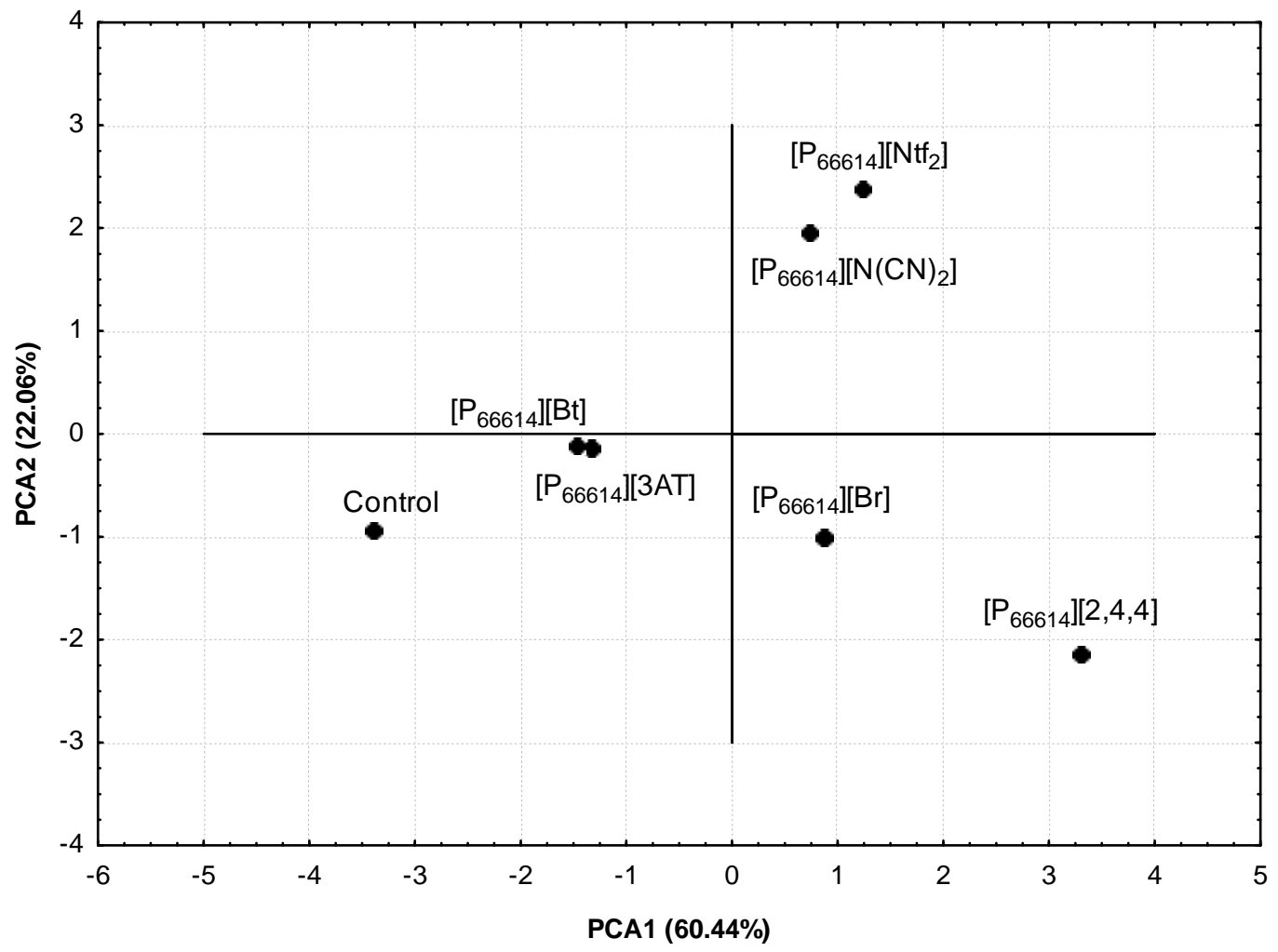

660

Fig. 4. PCA plot representing the weighted Unifrac distances for control and soils treated with 662 the studied phosphonium-based ILs.

663

664

665

666

667

668

669

670

671

672

673

674

675

676

677

678 
Table 1. The acronyms, structures and names of the used phosphonium-based ILs.

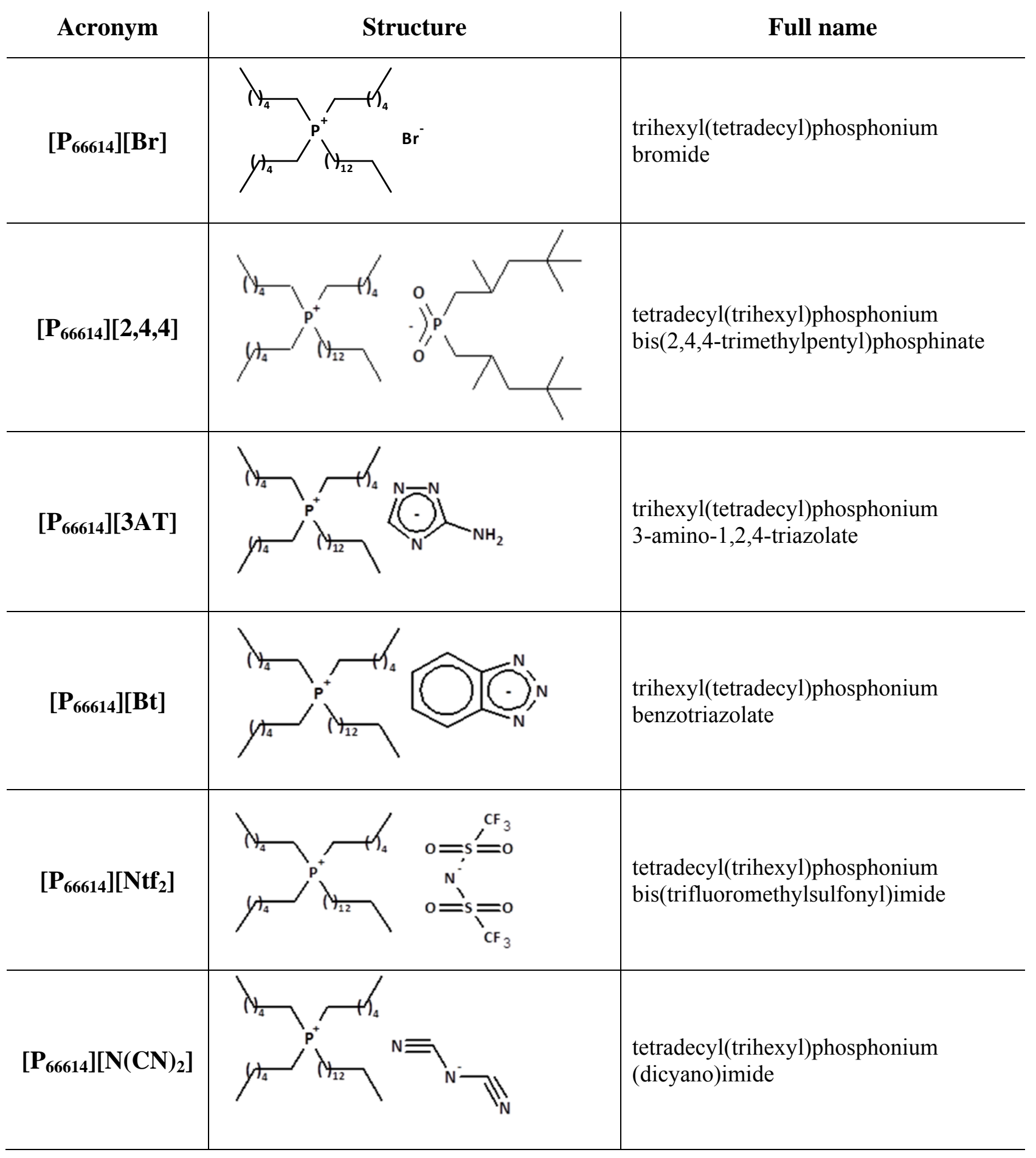




\begin{tabular}{|c|c|c|}
\hline Soil sample & OTU's observed & Shannon's index \\
\hline Control & $1399 \pm 28^{\mathrm{b}, \mathrm{c}, \mathrm{d}, \mathrm{e}, \mathrm{f}, \mathrm{g}}$ & $1.75 \pm 0.04^{\mathrm{b}, \mathrm{c}, \mathrm{d}, \mathrm{e}, \mathrm{f}, \mathrm{g}}$ \\
\hline $\left.\mathbf{P}_{66614}\right][\mathrm{Br}]$ & $1008 \pm 62^{\mathrm{a}, \mathrm{b}, \mathrm{c}, \mathrm{d}, \mathrm{e}}$ & $1.34 \pm 0,06^{\mathrm{a}, \mathrm{b}, \mathrm{c}, \mathrm{d}, \mathrm{g}}$ \\
\hline$\left[P_{66614}\right][2,4,4]$ & $965 \pm 55^{\mathrm{a}, \mathrm{b}, \mathrm{c}, \mathrm{d}, \mathrm{e}}$ & $0.73 \pm 0,09^{\mathrm{a}, \mathrm{b}, \mathrm{c}, \mathrm{d}, \mathrm{e}, \mathrm{f}}$ \\
\hline$\left[\mathbf{P}_{66614}\right][3 \mathrm{AT}]$ & $1205 \pm 31^{\mathrm{a}, \mathrm{e}, \mathrm{f}}$ & $1.57 \pm 0.08^{\mathrm{a}, \mathrm{e}, \mathrm{f}, \mathrm{g}}$ \\
\hline$\left[\mathbf{P}_{66614}\right][\mathrm{Bt}]$ & $1229 \pm 43^{\mathrm{a}, \mathrm{e}, \mathrm{f}}$ & $1.59 \pm 0.07^{\mathrm{a}, \mathrm{e}, \mathrm{f}, \mathrm{g}}$ \\
\hline$\left[P_{66614}\right]\left[\mathrm{Ntf}_{2}\right]$ & $1296 \pm 58^{\mathrm{a}, \mathrm{e}, \mathrm{f}}$ & $1.48 \pm 0,05^{\mathrm{a}, \mathrm{e}, \mathrm{f}, \mathrm{g}}$ \\
\hline$\left[\mathbf{P}_{66614}\right]\left[\mathrm{N}(\mathrm{CN})_{2}\right]$ & $1258 \pm 39^{\mathrm{a}, \mathrm{e}, \mathrm{f}}$ & $1.27 \pm 0,04^{\mathrm{a}, \mathrm{b}, \mathrm{c}, \mathrm{d}, \mathrm{g}}$ \\
\hline
\end{tabular}

Table 2. Alpha diversity estimates. Superscripts a,b,c,d,e,f,g correspond to the following table rows ( $1^{\text {st }}$ row is $a, 7^{\text {th }}$ row is $g$ ) and describe which rows differ significantly at $\mathrm{p} \leq 0.05$. 